\title{
Title: Repurposing of approved drugs with potential to block SARS-CoV-2 surface glycoprotein interaction with host receptor
}

Authors: Abu Ashfaqur Sajib*

\section{Author affiliation:}

Department of Genetic Engineering \& Biotechnology, University of Dhaka, Dhaka-1000, Bangladesh.

Emails:

Author Name

Abu Ashfaqur Sajib

\section{Email}

abu.sajib@du.ac.bd

*Corresponding author:

Dr. Abu Ashfaqur Sajib

Department of Genetic Engineering and Biotechnology, University of Dhaka, Dhaka-1000, Bangladesh.

Email: abu.sajib@du.ac.bd

Phone: +88-01981910626 


\title{
Repurposing of approved drugs with potential to block SARS-CoV-2 surface glycoprotein interaction with host receptor
}

\begin{abstract}
Background: Respiratory transmission is the primary route of SARS-CoV-2 infection. Angiotensin I converting enzyme 2 (ACE2) is the known receptor of SARS-CoV-2 spike glycoprotein for entry into human cells. A recent study reported absent to low ACE2 promoter activity in a variety of human lung epithelial cell samples. Three bioprojects (PRJEB4337, $\underline{\text { PRJNA270632 }}$ and PRJNA280600) invariably found abundant expression of ACE in human lungs compared to very low expression of ACE2. Methods: In silico tools were applied to assess potential interaction of SARS-CoV-2 surface spike protein with human ACE as well as predict the drugs that may block SARS-CoV-2 interaction with host receptor. Results: Although it is not obvious from the primary sequence alignment of ACE2 and its homolog ACE (also known as ACE1), comparison of X-ray crystallographic structures show striking similarity in the regions of these proteins which is known (for ACE2) to interact with the receptor binding domain (RBD) of SARS-CoV-2 spike protein. Critical amino acids that mediate interaction with the viral spike protein in ACE2 are organized in the same order in ACE. In silico analyses predicts comparable interaction of SARS-CoV-2 spike protein with ACE2 and ACE. In addition, this study predicts and selects already approved drugs from a list of 1263, which may interfere with the binding of SARS-CoV-2 spike glycoprotein to ACE2 and/or ACE.
\end{abstract}

Key words: COVID-19; SARS-CoV-2; Spike protein; ACE; ACE2.

\section{Introduction}

Coronavirus disease-19 (COVID-19) is caused by the Severe Acute Respiratory Syndrome Coronavirus 2 (SARS-CoV-2). Corona viruses are enveloped viruses with a positivesense, single-stranded ribonucleic acid (RNA) genome [1]. Respiratory transmission is the primary route of SARS-CoV-2 infection [2]. SARS-CoV-2 shares a similar mechanism with 
SARS-CoV (caused an outbreak in 2003) in making its way to the host cell [3,4]. Angiotensin I converting enzyme 2 (ACE2) is the known cellular receptor for both SARS-CoV and SARSCoV-2 in human $[3,5]$. The receptor binding domain (RBD) of the surface spike glycoprotein (S protein) of these viruses interact with the extracellular peptidase domain (PD) of ACE2 using electrostatic as well as van der Waals forces [3,6]. Despite the overall similarity in structure, SARS-COV-2 spike protein has evolved with a number of sequence variations and conformational deviations from that of SARS-CoV in the RBD at the interface with ACE2 [3,5]. Structural analyses have revealed key atomic-level interactions between the SARS-CoV-2 spike protein RBD and ACE2 [3,5]. Binding ability of SARS-CoV-2 has evolved [5]. SARS-CoV-2 is assumed to bind human ACE2 more efficiently using its modified spike protein than the SARS$\mathrm{CoV}$ [5]. Binding affinity of the spike protein to ACE2 is one of the most important determinants of SARS-CoV-2 infectivity [5]. SARS-CoV-2 might have gained its high capability to infect and transmit in humans through enhanced binding.

The primary physiological role of ACE2 is in the maturation of angiotensin, which controls vasoconstriction and blood pressure [7]. ACE2 is a homolog of angiotensin converting enzyme (ACE) with subtle differences in the active site [8,9]. Whereas ACE2 act as a carboxypeptidase by removing a single amino acid from the C-terminus of susceptible substrates, ACE acts as a carboxy-dipeptidase (or, peptidyl-dipeptidase) and removes a C-terminal dipeptide [10]. A recent study reported absent to low ACE2 promoter activity in a variety of human lung epithelial cell


found very low expression of ACE2 in human lungs, whereas ACE was found to be much highly expressed (Supplementary figure 1-3) [12]. Although it is not obvious from the primary sequence alignment, ACE has striking similarity in the PD region with ACE2 that interact with the SARSCoV-2 spike protein.

Till April 13, 2020 COVID-19 has spread in 213 countries and regions on earth with over 1,775,000 confirmed cases of infection and more than 112,000 deaths. Despite an urgent need to find options to help tens of thousands of patients and preclude potential death, there is no proven therapy to treat COVID-19 [13]. Repurposing of already approved drugs, if available, may be an immediate and promising option to tackle COVIDd-19. It is unlikely for the virus to mutate and evolve to bind an entirely different receptor within days or even months as such functional 
relationships are established by evolution over a long period of time [13]. Therefore, one strategy might be the use of an agent that binds to the receptor region recognized by the RBD of SARSCoV-2 spike protein.

Since SARS-CoV-2 has evolved with increased affinity of the surface spike protein for its known receptor ACE2, this study explored the possibility of interaction of this spike protein with its ACE- a homolog of ACE2, which is more abundant in human lungs. This study also investigated the potential of 1263 already approved drugs to bind and interfere at the interface of ACE and ACE2 with the SARS-CoV-2 S protein.

\section{Methods}

\subsection{Comparison of X-ray crystallographic structures of ACE and ACE2}

X-ray crystallographic structures of human ACE (PDB ID:1O86) [14], ACE2 (PDB ID: 6LZG) [15] and SARS-CoV-2 spike protein (PDB ID: 6VYB) [16] were retrieved from the Research Collaboratory for Structural Bioinformatics (RCSB) Protein Data Bank (PDB) [17]. These structures were processed (removal of HETATM, inhibitor and monomerization) using Discovery Studio Visualizer (v20.1.0.19295) [18]. 3D structures were aligned using RaptorX alignment tool [19]. Aligned 3D models were analyzed using CCP4mg [20].

\subsection{Prediction of interaction between ACE and SARS-CoV-2 surface spike glycoprotein}

Interaction of ACE and ACE2 with and SARS-CoV-2 surface spike glycoprotein were predicted using HADDOCK2.2 tool [21]. Predicted protein complexes were analyzed using PyMOL [22] and CCP4mg [20]. 


\subsection{In silico assessment of drugs with potentials to block SARS-CoV-2 spike protein interaction with $\mathrm{ACE}$ and $\mathrm{ACE} 2$}

1263 approved drugs (Supplementary table 1) in 3D SDF format were retrieved from DrugBank [23], BindingDB [24], e-Drug3D [25] databases. Interaction of these drugs with ACE and ACE2 were predicted using AutoDock Vina in PyRx [26,27]. These structures were further analyzed using CCP4mg [20].

\section{Results and discussion}

\subsection{Interaction between ACE and SARS-CoV-2 surface spike glycoprotein}

Based on the sequence similarities to SARS-CoV spike proteins, it has been suggested that SARS-CoV-2 also exploits ACE2 to mediate infection in human cells [5]. Alignment of X-ray crystallographic structures of ACE and ACE2 reveals striking similarities in the tertiary structures of the PD regions that interact with the RBD of SARS-CoV-2 spike protein (Figure 1A). Critical amino acids in this region of ACE2 [3,5] that interact with the spike protein occupy similar positions in ACE (Figure 1B and C). Lys31 and Lys 353 in ACE2 are particularly considered as critical in the PD of ACE2 for interaction with the viral spike protein [5]. Although it is not obvious in the primary sequence alignment, these important amino acid residues in the PD of ACE and ACE2 are present in the same order (Figure 1B).

Receptor-ligand interaction analysis using molecular docking technique could predict the amino acids at the interface of ACE and ACE2 PD regions with RBD of the spike protein (Figure 2). Although amino acid residues at the interface of ACE2 and spike proteins are already known from X-ray crystallographic analysis, this in silico prediction was performed as control to compare with the predicted analysis between ACE and S protein. The amino acid residues in ACE2 at the interface with the SARS-CoV-2 spike protein matched to the previous reports [3,5]. Similar interactions were observed in the predicted interactions between ACE and the spike 
protein. Predicted interactions of ACE and ACE2 with the spike protein involve similar forces and z-scores (Supplementary table 2). As in SARS-CoV/SARS-CoV-2 and ACE2 [5], the predicted interface between SARS-CoV-2 and ACE maintains a highly polar environment (Figure 2). In fact, the predicted interaction model suggests (Supplementary table 2) the ACEspike protein complex to be electrostatically more stable than the ACE2-spike protein complex. As SARS-CoV-2 spike protein has evolved to bind ACE2 with higher affinity than does the SARS-CoV [4] and gained more power to transmit and infect humans, mere speculation based on sequence comparison with SARS-CoV might not be enough to define its receptor.

\subsection{In silico assessment of drugs with potentials to block SARS-CoV-2 spike protein interaction with $\mathrm{ACE}$ and $\mathrm{ACE} 2$}

A total of 1263 approved drugs (Supplementary table 1) were assessed for potential interactions with $\mathrm{ACE}$ and ACE2 at regions that overlap with the predicted and known binding regions of RBD of the SARS-COV-2 spike protein, respectively. Angiotensin II is a substrate of ACE2 [10]. Molecular docking with AutoDock Vina predicted an interaction of angiotensin II with the PD of ACE2 with a binding energy of $-6.0 \mathrm{kcal} / \mathrm{mol}$. Drugs that bind to overlapping regions in the PD of ACE and ACE2 and, therefore, may perturb interaction with the SARS-CoV-2 spike protein and has more stable binding than the native substrate (i.e., predicted to release energy > $6.0 \mathrm{kcal} / \mathrm{mol}$ ) are listed in table 1 . Several of these predicted interactions are shown in figure 3 and 4. Table 1 also provides brief description of the drugs along with their current approval status. Some drugs have multiple statuses as these have been approved for certain condition(s), but are currently on clinical trials for one or more different indications.

There are differences between the compositions and structures of ACE and ACE2. Based on in silico analysis, among the 1263 analyzed drugs in this study, only 10 may bind to regions in both ACE and ACE2 that overlap with the binding sites of the key interacting spike protein amino acid residues. Pibrentasvir is one such drug which is used to treat infection mediated by Hepatitis C Virus (HCV)- a positive-strand RNA virus [28]. In silico analysis could predict a few more antiviral drugs (Indinavir, Baloxavir marboxil, Maraviroc, Doravirine, and Nelfinavir), which 
may interfere with the binding of SARS-CoV-2 spike protein with ACE2 only. Several of the drugs may play dual roles by blocking the binding of virus to the receptor as well as fight other associated infections. For example, Azithromycin, Cefoperazone, Natamycin, Nystatin, Rifapentine, etc may be used to manage infection as well as interfere with SARS-CoV-2 binding. These may serve as a two edged sword by blocking the binding to the receptor as well as inhibiting secondary infections [29]. Two angiotensin II analogs (Azilsartan kamedoxomil and Saralasin) were predicted to bind with higher affinity to ACE2 than angiotensin II. These two drugs bind to regions that overlap with the binding site of SARS-CoV spike protein. Mefloquinean anti-malarial drug may compete with spike protein for ACE2 rather than Hydroxychloroquine, which binds to other region of ACE2 (Table 1 and supplementary table 1).

\section{Conclusion}

Although there has been discussion on whether it would be safe to use angiotensin receptor blockers (ARB) in the treatment of COVID-19, the Council on Hypertension of the European Society of Cardiology, the American Heart Association, the Heart Failure Society of America, and the American College of Cardiology recommended that the physicians and patients should continue treatment with their usual anti-hypertensive therapy because there is no clinical or scientific evidence to suggest that treatment with angiotensin-converting enzyme inhibitors (ACEIs) and angiotensin receptor blockers (ARBs) should be discontinued because of the COVID-19 infection [30,31]. In an acid lung injury model of mice SARS-CoV worsened lung injury by down-regulation of ACE2, which was improved by treatment with angiotensin receptor blocker (ARB) [32].

No specific therapeutics for COVIDD-19 is yet available. A better understanding of the underlying pathobiology will be useful in finding a cure [33]. Till then, already available potential options might be explored to bring comfort to the world.

Conflict of interests: There is no known conflict of interest. 
Acknowledgements: This study was supported by a grant from the innovation fund (2019-2020)

of the ICT Division, Ministry of Posts, Telecommunications and Information Technology, Bangladesh.

\section{References}

1. Pal M, Berhanu G, Desalegn C, Kandi V (2020) Severe Acute Respiratory Syndrome Coronavirus-2 (SARS-CoV-2): An update. Cureus 12: Article ID-e7423.

2. Wu Y, Guo C, Tang L, Hong Z, Zhou J, et al. (2020) Prolonged presence of SARS-CoV-2 viral RNA in faecal samples. Lancet Gastroenterol Hepatol pii: S2468-1253: 30083-30082.

3. Yan R, Zhang Y, Li Y, Xia L, Guo Y, et al. (2020) Structural basis for the recognition of SARS-CoV-2 by full-length human ACE2. Science 367: 1444-1448.

4. Wrapp D, Wang N, Corbett KS, Goldsmith JA, Hsieh CL, et al. (2020) Cryo-EM structure of the 2019nCoV spike in the prefusion conformation. Science 367: 1260-1263v.

5. Wan Y, Shang J, Graham R, Baric RS, Li F (2020) Receptor recognition by the novel Coronavirus from Wuhan: an analysis based on decade-long structural studies of SARS Coronavirus. J Virol 94.

6. Xu X, Chen P, Wang J, Feng J, Zhou H, et al. (2020) Evolution of the novel coronavirus from the ongoing Wuhan outbreak and modeling of its spike protein for risk of human transmission. Sci China Life Sci 63: 457-460.

7. Guang C, Phillips RD, Jiang B, Milani F (2012) Three key proteases--angiotensin-I-converting enzyme (ACE), ACE2 and renin--within and beyond the renin-angiotensin system. Arch Cardiovasc Dis 105: 373-385.

8. Guy JL, Jackson RM, Acharya KR, Sturrock ED, Hooper NM, et al. (2003) Angiotensin-converting enzyme-2 (ACE2): comparative modeling of the active site, specificity requirements, and chloride dependence. Biochemistry 42: 13185-13192.

9. Raizada MK, Ferreira AJ (2007) ACE2: a new target for cardiovascular disease therapeutics. J Cardiovasc Pharmacol 50: 112-119.

10. Clarke NE, Turner AJ (2012) Angiotensin-converting enzyme 2: the first decade. Int J Hypertens 2012: Articile ID- 307315.

11. Aguiar JA, Tremblay B J-M, Mansfield MJ, Woody O, Lobb B, et al. (2020) Gene expression and in situ protein profiling of candidate SARS-CoV-2 receptors in human airway epithelial cells and lung tissue. bioRxiv doi: https://doi.org/10.1101/2020.04.07.030742

12. Sayers EW, Beck J, Brister JR, Bolton EE, Canese K, et al. (2020) Database resources of the National Center for Biotechnology Information. Nucleic Acids Res 48: D9-D16.

13. Kruse RL (2020) Therapeutic strategies in an outbreak scenario to treat the novel coronavirus originating in Wuhan, China. F1000Res 9: Article ID-72.

14. Natesh R, Schwager SL, Sturrock ED, Acharya KR (2003) Crystal structure of the human angiotensinconverting enzyme-lisinopril complex. Nature 421: 551-554. 
15. Wang QH, Song H, Qi JX (2020) Structure of novel coronavirus spike receptor-binding domain complexed with its receptor ACE2. doi: 102210/pdb6LZG/pdb.

16. Walls AC, Park YJ, Tortorici MA, Wall A, McGuire AT, et al. (2020) Structure, function, and antigenicity of the SARS-CoV-2 spike glycoprotein. Cell pii: S0092-8674: 30262-30262.

17. Berman HM, Westbrook J, Feng Z, Gilliland G, Bhat TN, et al. (2000) The Protein Data Bank. Nucleic Acids Res 28: 235-242.

18. Dassault Systèmes BIOVIA Corp. (2020) Discovery Studio Visualizer v20.1.0.19295. San Diego, USA.

19. Källberg M, Margaryan G, Wang S, Ma J, Xu J (2014) RaptorX server: a resource for template-based protein structure modeling. Methods Mol Biol 1137v: 17-27.

20. McNicholas S, Potterton E, Wilson KS, Noble ME (2011) Presenting your structures: the CCP4mg molecular-graphics software. Acta Crystallogr D Biol Crystallogr 67: 386-394.

21. van Zundert GCP, Rodrigues J, Trellet M, Schmitz C, Kastritis PL, et al. (2016) The HADDOCK2.2 Web Server: User-Friendly Integrative Modeling of Biomolecular Complexes. J Mol Biol 428: 720-725.

22. Delano WL (2004) Use of PyMOL as a communications tool for molecular science (Abstract paper). Am Chem Soc 228: U228-U230.

23. Wishart DS, Feunang YD, Guo AC, Lo EJ, Marcu A, et al. (2018) DrugBank 5.0: a major update to the DrugBank database for 2018. Nucleic Acids Res 46: D1074-D1082.

24. Gilson MK, Liu T, Baitaluk M, Nicola G, Hwang L, et al. (2016) BindingDB in 2015: A public database for medicinal chemistry, computational chemistry and systems pharmacology. Nucleic Acids Res 44: D1045-1053.

25. Douguet D (2018) Data sets representative of the structures and experimental properties of FDAapproved drugs. ACS Med Chem Lett 9: 204-209.

26. Trott O, Olson AJ (2010) AutoDock Vina: improving the speed and accuracy of docking with a new scoring function, efficient optimization, and multithreading. J Comput Chem 31: 455-461.

27. Dallakyan S, Olson AJ (2015) Small-Molecule Library Screening by Docking with PyRx. . Methods Mol Biol 1263: 243-250.

28. Patel AB, Verma A (2020) COVID-19 and Angiotensin-Converting Enzyme Inhibitors and Angiotensin Receptor Blockers: What Is the Evidence? JAMA.

29. Lupia T, Scabini S, Mornese Pinna S, Di Perri G, De Rosa FG, et al. (2020) 2019 novel coronavirus (2019-nCoV) outbreak: A new challenge. J Glob Antimicrob Resist 21: 22-27.

30. European Society of Cardiology (2020) Position statement of the ESC Council on Hypertension on ACE-inhibitors and angiotensin receptor blockers. https://wwwescardioorg/Councils/Council-onHypertension-(CHT)/News/position-statement-of-the-esc-council-on-hypertension-on-aceinhibitors-and-ang Published March 13, 2020. Accessed April 02, 2020.

31. American Heart Association, Heart Failure Society of America, American College of Cardiology (2020) HFSA/ACC/AHA statement addresses concerns re: using RAAS antagonists in COVID-19. https://professionalheartorg/professional/ScienceNews/UCM_505836_HFSAACCAHAstatement-addresses-concerns-re-using-RAAS-antagonists-in-COVID-19jsp Accessed April 02, 2020.

32. Kuba K, Imai Y, Rao S, Gao H, Guo F, et al. (2005) A crucial role of angiotensin converting enzyme 2 (ACE2) in SARS coronavirus-induced lung injury. Nat Med 11: 875-879.

33. Zhang H, Penninger JM, Li Y, Zhong N, Slutsky AS (2020) Angiotensin-converting enzyme 2 (ACE2) as a SARS-CoV-2 receptor: molecular mechanisms and potential therapeutic target. Intensive Care Med 46: 586-590. 

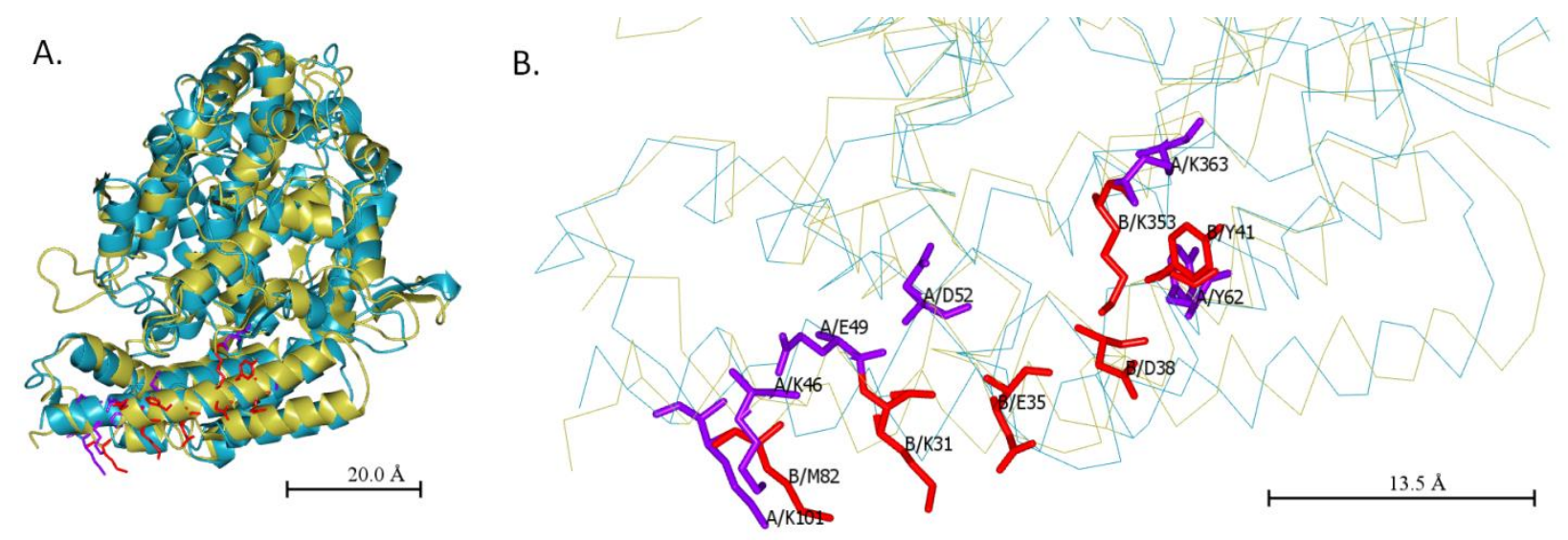

Figure 1: Alignment of X-ray crystallographic structures of ACE (PDB ID:1O86) and ACE2 (PDB ID: 6LZG). A. SARS-CoV-2 spike protein binding region (RBD) of ACE (in dark cyan) and ACE2 (in gold) have similar tertiary structures in the PD region. B. K46, E49, D52, Y62, $\mathrm{K} 101$, and $\mathrm{K} 363$ in ACE (in red) are positioned in similar order to K31, E35, D38, Y41, M82, and $\mathrm{K} 353$ in ACE2 (in purple). Chain A and B represent ACE and ACE2, respectively.

\section{A.}



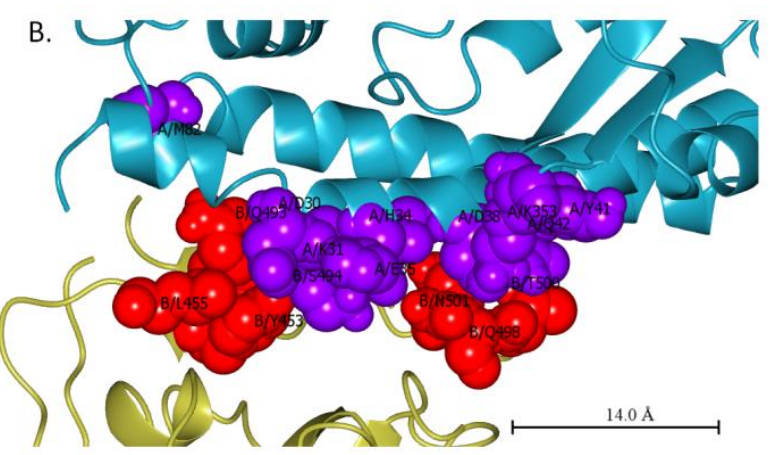

Figure 2: Predicted interactions of ACE and ACE2 with the RBD of SARS-CoV-2 surface spike protein. A and B. Interaction of ACE and ACE2 PD regions (in dark cyan) with the RBD of SARS-CoV-2 spike protein (in gold) are shown. Interacting amino acid residues in ACE and ACE2 are shown in purple, whereas those in $\mathrm{S}$ protein are shown in red. Chain A and B represent ACE/ACE2 and spike protein, respectively. 

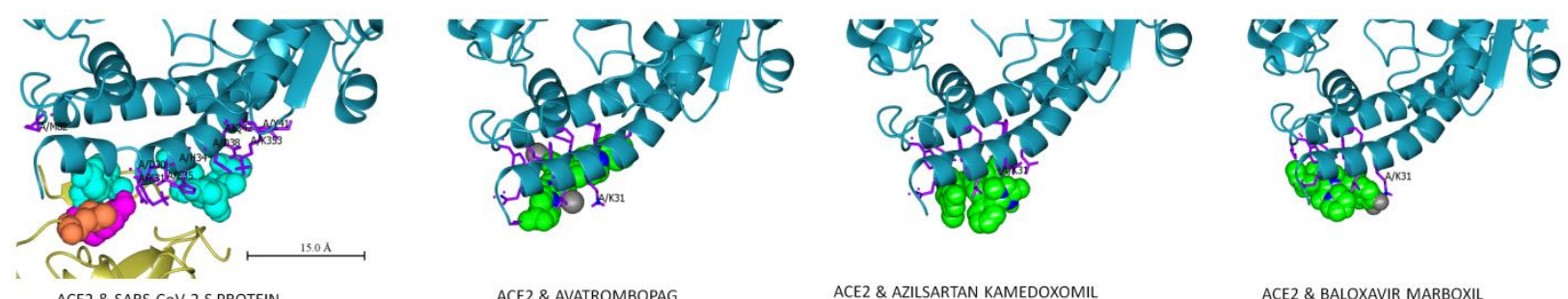

ACE2 \& SARS-COV-2 S PROTEIN

ACE2 \& AVATROMBOPAG

ACE2 \& AZILSARTAN KAMEDOXOMIL.

ACE2 \& BALOXAVIR MARBOXIL

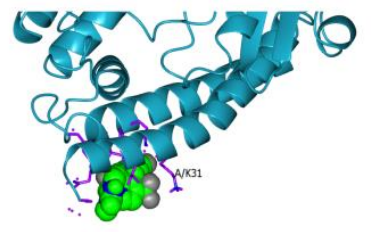

ACE2 \& DORAVIRINE
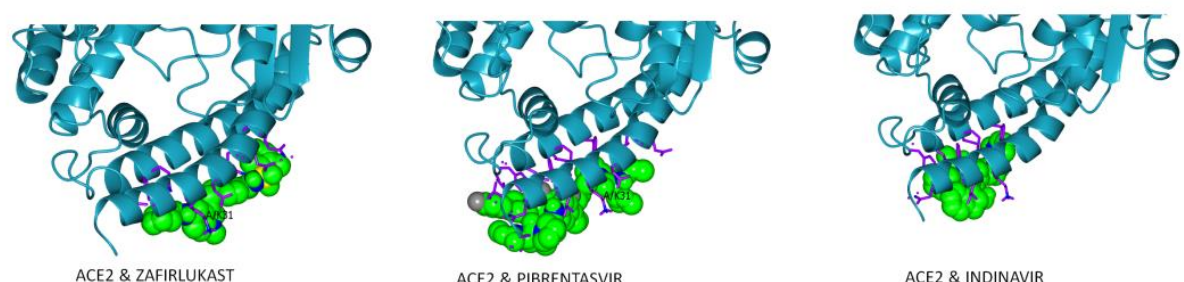

ACE2 \& INDINAVIR

Figure 3: Drugs with potential binding abilities to ACE2 at the interface with RBD of SARSCoV-2 surface spike protein. Interacting amino acid residues in ACE2 are shown in purple and drug molecules are shown as spheres. Chain A represents ACE2 enzyme.
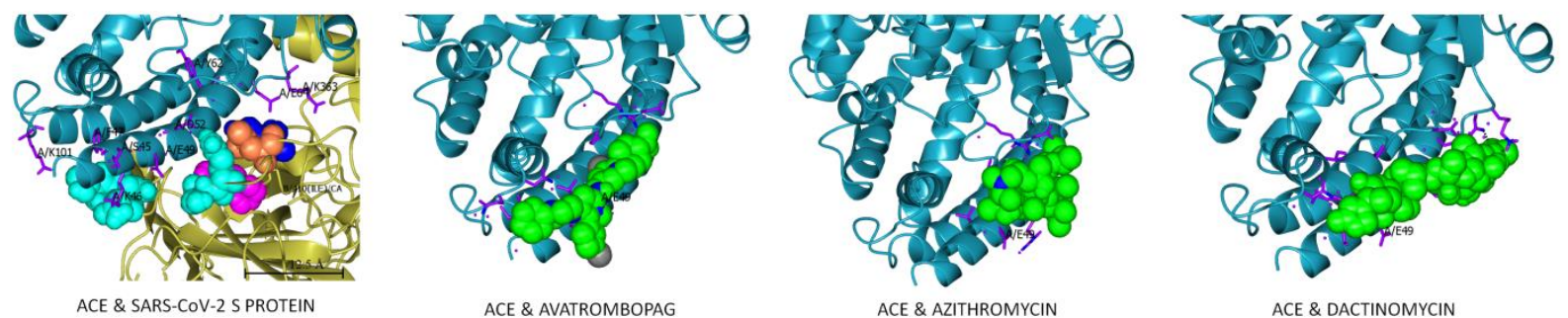

ACE \& AVATROMBOPAG

ACE \& DACTINOMYCIN

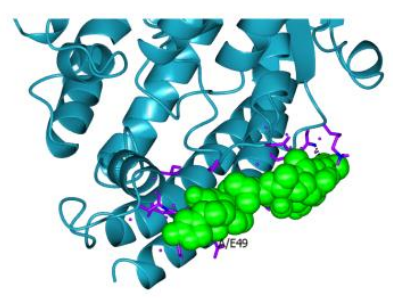

ACE \& DESLANOSIDE
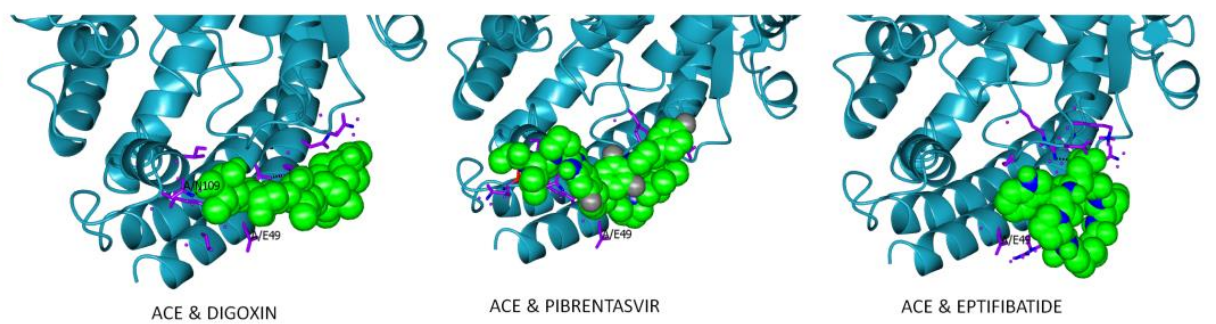

ACE \& EPTIFIBATIDE

Figure 4: Drugs with potential binding abilities to ACE at the interface with RBD of SARSCoV-2 surface spike protein. Interacting amino acid residues in ACE are shown in purple and drug molecules are shown as spheres. Chain A represents ACE enzyme. 
Table 1: List of drugs that bind to ACE and ACE2 PD regions and has more stable binding than angiotensin II (i.e., predicted to release energy $>6.0 \mathrm{kcal} / \mathrm{mol}$ ).

\begin{tabular}{|c|c|c|c|c|}
\hline \multirow[b]{2}{*}{ Ligand } & \multicolumn{2}{|c|}{ Binding energy } & \multirow[b]{2}{*}{ Status [23] } & \multirow[b]{2}{*}{ Description [23] } \\
\hline & $\begin{array}{l}\text { Human } \\
\text { ACE }\end{array}$ & $\begin{array}{l}\text { Human } \\
\text { ACE2 }\end{array}$ & & \\
\hline DIGITOXIN & - & -8 & Approved & A cardiac glycoside sometimes used in place of digoxin. \\
\hline NILOTINIB & - & -7.7 & $\begin{array}{l}\text { Approved, } \\
\text { Investigational }\end{array}$ & $\begin{array}{l}\text { A tyrosine kinase inhibitor under investigation as a } \\
\text { possible treatment for chronic myelogenous leukemia } \\
\text { (CML). A Phase I clinical trial showed that this drug } \\
\text { was relatively safe and offered significant therapeutic } \\
\text { benefits in cases of CML. }\end{array}$ \\
\hline VILAZODONE & - & -7.6 & Approved & $\begin{array}{l}\text { A novel compound with combined high affinity and } \\
\text { selectivity for the 5-hydroxytryptamine (5-HT) } \\
\text { transporter and 5-HT(1A) receptors. }\end{array}$ \\
\hline AVATROMBOPAG & -6.9 & -7.4 & $\begin{array}{l}\text { Approved, } \\
\text { Investigational }\end{array}$ & $\begin{array}{l}\text { An orally administered thrombopoietin receptor (c-Mpl) } \\
\text { agonist which increases platelet number, but not platelet } \\
\text { activation. }\end{array}$ \\
\hline $\begin{array}{l}\text { DIHYDROERGOTAMIN } \\
\text { E }\end{array}$ & - & -7.4 & Approved & $\begin{array}{l}\text { Used as a vasoconstrictor, specifically for the therapy of } \\
\text { migraine disorders. }\end{array}$ \\
\hline ACALABRUTINIB & - & -7.2 & $\begin{array}{l}\text { Approved, } \\
\text { Investigational }\end{array}$ & $\begin{array}{l}\text { Indicated for the treatment of chronic lymphocytic } \\
\text { leukemia, small lymphocytic lymphoma, and in adult } \\
\text { patients with Mantle Cell Lymphoma (MCL). }\end{array}$ \\
\hline INDINAVIR & - & -7.1 & Approved & $\begin{array}{l}\text { A potent and specific HIV protease inhibitor that appears } \\
\text { to have good oral bioavailability. }\end{array}$ \\
\hline SARALASIN & - & -7.1 & Investigational & $\begin{array}{l}\text { An octapeptide analog of angiotensin II (bovine) with } \\
\text { amino acids } 1 \text { and } 8 \text { replaced with sarcosine and alanine, } \\
\text { respectively. }\end{array}$ \\
\hline ZAFIRLUKAST & - & -7.1 & $\begin{array}{l}\text { Approved, } \\
\text { Investigational }\end{array}$ & $\begin{array}{l}\text { An oral leukotriene receptor antagonist (LTRA) for the } \\
\text { maintenance treatment of asthma, often used in } \\
\text { conjunction with an inhaled steroid and/or long-acting } \\
\text { bronchodilator. }\end{array}$ \\
\hline PACLITAXEL & - & -6.9 & Approved & Used as a treatment for various cancers. \\
\hline APALUTAMIDE & - & -6.8 & $\begin{array}{l}\text { Approved, } \\
\text { Investigational }\end{array}$ & $\begin{array}{l}\text { A potent androgen receptor (AR) antagonist that } \\
\text { selectively binds to the ligand-binding domain of AR } \\
\text { and blocks AR nuclear translocation or binding to } \\
\text { androgen response elements. }\end{array}$ \\
\hline TERCONAZOLE & - & -6.8 & Approved & $\begin{array}{l}\text { An anti-fungal drug that is mainly used to treat vaginal } \\
\text { yeast infections. }\end{array}$ \\
\hline ABEMACICLIB & - & -6.7 & $\begin{array}{l}\text { Approved, } \\
\text { Investigational }\end{array}$ & $\begin{array}{l}\text { An antitumor agent and dual inhibitor of cyclin- } \\
\text { dependent kinases } 4 \text { (CDK4) and } 6 \text { (CDK6). }\end{array}$ \\
\hline DARIFENACIN & - & -6.7 & $\begin{array}{l}\text { Approved, } \\
\text { Investigational }\end{array}$ & Used to treat urinary incontinence. \\
\hline METOCURINE & - & -6.7 & Approved & A non-depolarizing muscle relaxant. \\
\hline $\begin{array}{l}\text { TESTOSTERONE } \\
\text { CYPIONATE }\end{array}$ & - & -6.7 & Approved & A synthetic derivative of testosterone. \\
\hline DESERPIDINE & - & -6.6 & Approved & $\begin{array}{l}\text { An antipsychotic and antihypertensive agent used for the } \\
\text { control of high blood pressure and for the relief of } \\
\text { psychotic behavior. }\end{array}$ \\
\hline NERATINIB & - & -6.6 & $\begin{array}{l}\text { Approved, } \\
\text { Investigational }\end{array}$ & $\begin{array}{l}\text { Used as an extended adjuvant therapy in Human } \\
\text { Epidermal Growth Factor Receptor } 2 \text { (HER2) positive } \\
\text { breast cancer. }\end{array}$ \\
\hline PIBRENTASVIR & -7.5 & -6.6 & $\begin{array}{l}\text { Approved, } \\
\text { Investigational }\end{array}$ & $\begin{array}{l}\text { A direct acting antiviral agent and Hepatitis } \mathrm{C} \text { virus } \\
\text { (HCV) NS5A inhibitor that targets viral RNA replication } \\
\text { and viron assembly. }\end{array}$ \\
\hline BETRIXABAN & - & -6.5 & $\begin{array}{l}\text { Approved, } \\
\text { Investigational }\end{array}$ & $\begin{array}{l}\text { A non-vitamin } \mathrm{K} \text { oral anticoagulant whose action is } \\
\text { driven by the competitive and reversible inhibition of the } \\
\text { factor Xa. }\end{array}$ \\
\hline
\end{tabular}




\begin{tabular}{|c|c|c|c|c|}
\hline CEFOPERAZONE & - & -6.5 & $\begin{array}{l}\text { Approved, } \\
\text { Investigational }\end{array}$ & $\begin{array}{l}\text { A semisynthetic broad-spectrum third-generation } \\
\text { antiobiotic effective against Pseudomonas infections. It } \\
\text { is used in the treatment of various bacterial infections, } \\
\text { including respiratory tract infections, peritonitis, skin } \\
\text { infections, endometritis, and bacterial septicemia. }\end{array}$ \\
\hline CELECOXIB & - & -6.5 & $\begin{array}{l}\text { Approved, } \\
\text { Investigational }\end{array}$ & $\begin{array}{l}\text { A selective nonsteroidal anti-inflammatory drug } \\
\text { (NSAID) which is known for its decreased risk of } \\
\text { causing gastrointestinal bleeding compared to other } \\
\text { NSAIDS. }\end{array}$ \\
\hline DOCETAXEL & - & -6.5 & $\begin{array}{l}\text { Approved, } \\
\text { Investigational }\end{array}$ & $\begin{array}{l}\text { An anti-mitotic chemotherapy medication used mainly } \\
\text { for the treatment of breast, ovarian, and non-small cell } \\
\text { lung cancer. }\end{array}$ \\
\hline DORAVIRINE & - & -6.5 & Approved & $\begin{array}{l}\text { An HIV-1 non-nucleoside reverse transcriptase inhibitor } \\
\text { (NNRTI) intended to be administered in combination } \\
\text { with other antiretroviral medicines. }\end{array}$ \\
\hline ESTROPIPATE & - & -6.5 & $\begin{array}{l}\text { Approved, } \\
\text { Investigational }\end{array}$ & It is a form of estrogen. \\
\hline IDARUBICIN & - & -6.5 & Approved & $\begin{array}{l}\text { It has activity against breast cancer, lymphomas and } \\
\text { leukemias, together with the potential for reduced } \\
\text { cardiac toxicity. }\end{array}$ \\
\hline LUSUTROMBOPAG & - & -6.5 & $\begin{array}{l}\text { Approved, } \\
\text { Investigational }\end{array}$ & $\begin{array}{l}\text { An orally bioavailable thrombopoietin receptor (TPOR) } \\
\text { agonist. }\end{array}$ \\
\hline RIFAPENTINE & -6.4 & -6.5 & $\begin{array}{l}\text { Approved, } \\
\text { Investigational }\end{array}$ & $\begin{array}{l}\text { An antibiotic drug used in the treatment of tuberculosis. } \\
\text { It inhibits DNA-dependent RNA polymerase activity in } \\
\text { susceptible cells. }\end{array}$ \\
\hline ALATROFLOXACIN & - & -6.4 & $\begin{array}{l}\text { Approved, } \\
\text { Withdrawn }\end{array}$ & It is a fluoroquinolone antibiotic. \\
\hline $\begin{array}{l}\text { AZILSARTAN } \\
\text { KAMEDOXOMIL }\end{array}$ & - & -6.4 & $\begin{array}{l}\text { Approved, } \\
\text { Investigational }\end{array}$ & $\begin{array}{l}\text { An angiotensin II receptor antagonist indicated for the } \\
\text { treatment of mild to moderate essential hypertension. }\end{array}$ \\
\hline $\begin{array}{l}\text { BALOXAVIR } \\
\text { MARBOXIL }\end{array}$ & - & -6.4 & $\begin{array}{l}\text { Approved, } \\
\text { Investigational }\end{array}$ & $\begin{array}{l}\text { An antiviral drug for the treatment of influenza A and } \\
\text { influenza B infections. }\end{array}$ \\
\hline BRIGATINIB & - & -6.4 & $\begin{array}{l}\text { Approved, } \\
\text { Investigational }\end{array}$ & $\begin{array}{l}\text { A reversible dual inhibitor of anaplastic lymphoma } \\
\text { kinase (ALK) and epidermal growth factor receptor } \\
\text { (EGFR). }\end{array}$ \\
\hline CLOFAZIMINE & - & -6.4 & $\begin{array}{l}\text { Approved, } \\
\text { Investigational }\end{array}$ & $\begin{array}{l}\text { A fat-soluble riminophenazine dye used for the } \\
\text { treatment of leprosy. }\end{array}$ \\
\hline GANIRELIX & -6.2 & -6.4 & Approved & $\begin{array}{l}\text { Ganirelix is an injectable competitive gonadotropin- } \\
\text { releasing hormone antagonist. }\end{array}$ \\
\hline RESERPINE & -6.3 & -6.4 & $\begin{array}{l}\text { Approved, } \\
\text { Investigational }\end{array}$ & Used as an antihypertensive and an antipsychotic drug. \\
\hline SIMVASTATIN & - & -6.4 & Approved & $\begin{array}{l}\text { Used to lower the risk of cardiovascular disease and } \\
\text { manage abnormal lipid levels by inhibiting the } \\
\text { endogenous production of cholesterol in the liver. }\end{array}$ \\
\hline CANDICIDIN & - & -6.3 & $\begin{array}{l}\text { Approved, } \\
\text { Withdrawn }\end{array}$ & $\begin{array}{l}\text { An antibiotic active against some fungi of the genus } \\
\text { Candida. }\end{array}$ \\
\hline LOPERAMIDE & - & -6.3 & Approved & $\begin{array}{l}\text { Long-acting synthetic antidiarrheals, which has no effect } \\
\text { on the adrenergic system or central nervous system, but } \\
\text { may antagonize histamine and interfere with } \\
\text { acetylcholine release locally. }\end{array}$ \\
\hline LORATADINE & - & -6.3 & $\begin{array}{l}\text { Approved, } \\
\text { Investigational }\end{array}$ & $\begin{array}{l}\text { Loratadine is a second generation antihistamine used to } \\
\text { manage symptoms of allergic rhinitis. }\end{array}$ \\
\hline MARAVIROC & - & -6.3 & $\begin{array}{l}\text { Approved, } \\
\text { Investigational }\end{array}$ & $\begin{array}{l}\text { A chemokine receptor antagonist drug that is designed to } \\
\text { act against HIV by interfering with the interaction } \\
\text { between HIV and CCR5 }\end{array}$ \\
\hline PIPECURONIUM & - & -6.3 & Approved & A non-depolarizing neuromuscular blocking agent. \\
\hline PLICAMYCIN & - & -6.3 & $\begin{array}{l}\text { Approved, } \\
\text { Investigational, } \\
\text { Withdrawn }\end{array}$ & $\begin{array}{l}\text { An antineoplastic antibiotic used in the treatment of } \\
\text { testicular cancer, Paget's disease of bone, and, rarely, the } \\
\text { management of hypercalcemia. }\end{array}$ \\
\hline CERULETIDE & -6.2 & -6.2 & Approved & $\begin{array}{l}\text { Exerts stimulatory effects on the gastric, biliary, and } \\
\text { pancreatic secretion, as well as on certain smooth } \\
\text { muscles. }\end{array}$ \\
\hline
\end{tabular}




\begin{tabular}{|c|c|c|c|c|}
\hline CETRORELIX & - & -6.2 & $\begin{array}{l}\text { Approved, } \\
\text { Investigational }\end{array}$ & $\begin{array}{l}\text { A synthetic hormone that blocks the effects of } \\
\text { Gonadotropin Releasing Hormone. }\end{array}$ \\
\hline $\begin{array}{l}\text { ESTRAMUSTINE } \\
\text { PHOSPHATE }\end{array}$ & - & -6.2 & $\begin{array}{l}\text { Approved, } \\
\text { Investigational }\end{array}$ & $\begin{array}{l}\text { Used to treat prostatic neoplasms; also has radiation } \\
\text { protective properties. }\end{array}$ \\
\hline FOSNETUPITANT & - & -6.2 & Approved & $\begin{array}{l}\text { An alternative treatment option for patients experiencing } \\
\text { chemotherapy-induced nausea and vomiting. }\end{array}$ \\
\hline NATAMYCIN & -7.4 & -6.2 & Approved & $\begin{array}{l}\text { It is used for a variety of fungal infections, mainly } \\
\text { topically. }\end{array}$ \\
\hline NELFINAVIR & - & -6.2 & Approved & A potent HIV-1 protease inhibitor. \\
\hline POSACONAZOLE & -7.8 & -6.2 & $\begin{array}{l}\text { Approved, } \\
\text { Investigational }\end{array}$ & $\begin{array}{l}\text { An antifungal drug that is used to treat invasive } \\
\text { infections by Candida species and Aspergillus species in } \\
\text { severely immunocompromised patients. }\end{array}$ \\
\hline ROMIDEPSIN & - & -6.2 & $\begin{array}{l}\text { Approved, } \\
\text { Investigational }\end{array}$ & $\begin{array}{l}\text { A selective inhibitor of histone deacetylase for the } \\
\text { treatment of cutaneous T-cell lymphoma (CTCL) or/and } \\
\text { peripheral T-cell lymphoma (PTCL). }\end{array}$ \\
\hline SOLIFENACIN & - & -6.2 & Approved & $\begin{array}{l}\text { A competitive muscarinic receptor antagonist indicated } \\
\text { to treat an overactive bladder with urinary incontinence, } \\
\text { urgency, and frequency. }\end{array}$ \\
\hline BUCLIZINE & - & -6.1 & Approved & $\begin{array}{l}\text { An antihistamine medication with both antiemetic and } \\
\text { anticholinergic effects. }\end{array}$ \\
\hline BUTENAFINE & - & -6.1 & Approved & A synthetic benzylamine antifungal agent. \\
\hline $\begin{array}{l}\text { ETOPOSIDE } \\
\text { PHOSPHATE }\end{array}$ & - & -6.1 & Approved & $\begin{array}{l}\text { A semisynthetic derivative of podophyllotoxin that } \\
\text { exhibits antitumor activity. Etoposide inhibits DNA } \\
\text { synthesis by forming a complex with topoisomerase II } \\
\text { and DNA. }\end{array}$ \\
\hline MEFLOQUINE & - & -6.1 & $\begin{array}{l}\text { Approved, } \\
\text { Investigational }\end{array}$ & $\begin{array}{l}\text { A phospholipid-interacting antimalarial drug (anti- } \\
\text { malarials). }\end{array}$ \\
\hline NAFARELIN & - & -6.1 & Approved & $\begin{array}{l}\text { A potent synthetic agonist of gonadotropin-releasing } \\
\text { hormone. }\end{array}$ \\
\hline PITAVASTATIN & - & -6.1 & Approved & $\begin{array}{l}\text { A lipid-lowering drug belonging to the statin class of } \\
\text { medications. }\end{array}$ \\
\hline DIGOXIN & -7.7 & - & Approved & $\begin{array}{l}\text { Used to manage atrial fibrillation and the symptoms of } \\
\text { heart failure. }\end{array}$ \\
\hline DACTINOMYCIN & -7.7 & - & $\begin{array}{l}\text { Approved, } \\
\text { Investigational }\end{array}$ & $\begin{array}{l}\text { It binds to DNA and inhibits RNA synthesis } \\
\text { (transcription), with chain elongation more sensitive } \\
\text { than initiation, termination, or release. }\end{array}$ \\
\hline VANCOMYCIN & -7.7 & - & Approved & $\begin{array}{l}\text { Antibacterial compound that inhibits bacterial cell wall } \\
\text { assembly. }\end{array}$ \\
\hline HISTRELIN & -7.5 & - & Approved & $\begin{array}{l}\text { A gonadotropin releasing hormone agonist that acts as a } \\
\text { potent inhibitor of gonadotropin }\end{array}$ \\
\hline DESLANOSIDE & -7.5 & - & Approved & A cardiotonic glycoside. \\
\hline SIROLIMUS & -7.5 & - & $\begin{array}{l}\text { Approved, } \\
\text { Investigational }\end{array}$ & $\begin{array}{l}\text { Acts by selectively blocking the transcriptional } \\
\text { activation of cytokines, thereby inhibiting cytokine } \\
\text { production. }\end{array}$ \\
\hline TEMSIROLIMUS & -7.4 & -6.1 & Approved & Used in the treatment of renal cell carcinoma. \\
\hline EPTIFIBATIDE & -7.4 & - & $\begin{array}{l}\text { Approved, } \\
\text { Investigational }\end{array}$ & $\begin{array}{l}\text { Synthetic cyclic hexapeptide that binds to platelet } \\
\text { receptor glycoprotein and inhibits platelet aggregation. }\end{array}$ \\
\hline TRIAZOLAM & - & -6.1 & Approved & $\begin{array}{l}\text { A short-acting benzodiazepine used in the treatment of } \\
\text { insomnia. (Withdrawn in the United Kingdom due to } \\
\text { risk of psychiatric adverse drug reactions.) }\end{array}$ \\
\hline ICATIBANT & -7.3 & - & $\begin{array}{l}\text { Approved, } \\
\text { Investigational }\end{array}$ & $\begin{array}{l}\text { A synthetic peptidomimetic drug that acts as an effective } \\
\text { and specific antagonist of bradykinin B2 receptors and } \\
\text { approved in the EU for use in hereditary angioedema. }\end{array}$ \\
\hline AMPHOTERICIN B & -7.1 & - & $\begin{array}{l}\text { Approved, } \\
\text { Investigational }\end{array}$ & $\begin{array}{l}\text { Shows a high order of in vitro activity against many } \\
\text { species of fungi and without effect on bacteria, } \\
\text { rickettsiae, and viruses. }\end{array}$ \\
\hline NYSTATIN & -6.8 & - & Approved & $\begin{array}{l}\text { A polyene antifungal drug that has broad-spectrum } \\
\text { fungicidal and fungistatic activity against a number of } \\
\text { yeasts and fungi, most notably Candida species }\end{array}$ \\
\hline
\end{tabular}




\begin{tabular}{|l|l|l|l|l|}
\hline ANIDULAFUNGIN & -6.6 & - & $\begin{array}{l}\text { Approved, } \\
\text { Investigational }\end{array}$ & $\begin{array}{l}\text { An anti-fungal drug with similar safety profile to } \\
\text { caspofungin. }\end{array}$ \\
\hline AZITHROMYCIN & -6.6 & - & Approved & $\begin{array}{l}\text { A broad-spectrum macrolide antibiotic with a long half- } \\
\text { life, which is primarily used for the treatment of } \\
\text { respiratory, enteric and genitourinary infections. }\end{array}$ \\
\hline GOSERELIN & -6.6 & - & Approved & $\begin{array}{l}\text { A synthetic hormone that stops the production of the } \\
\text { hormone testosterone in men. }\end{array}$ \\
\hline RIFAXIMIN & -6.6 & - & $\begin{array}{l}\text { A semisynthetic, rifamycin-based non-systemic } \\
\text { antibiotic, used in treatment of traveller's diarrhea caused } \\
\text { by E. coli; reduction in risk of overt hepatic } \\
\text { encephalopathy recurrence; as well as diarrhea- } \\
\text { predominant irritable bowel syndrome (IBS-D) in adult. }\end{array}$ \\
\hline RIFAMYCIN & -6.3 & - & $\begin{array}{l}\text { Approved, } \\
\text { Investigational }\end{array}$ & $\begin{array}{l}\text { The first antibiotic used intravenously for the treatment } \\
\text { of tuberculosis. }\end{array}$ \\
\hline TRIPTORELIN & -6.3 & - & Approved & $\begin{array}{l}\text { A synthetic decapeptide agonist analog of luteinizing } \\
\text { hormone releasing hormone. }\end{array}$ \\
\hline VASOPRESSIN & -6.1 & - & Approved & Antidiuretic hormone. \\
\hline
\end{tabular}





Supplementary figure 1: Expression of ACE and ACE2 in different human tissues (BioProject accession number: PRJEB4337) [12]. RNA-seq was performed of tissue samples from 95 human individuals representing 27 different tissues in order to determine tissue-specificity of all protein-coding genes. The plots are adopted and modified from [12]. RPKM- Reads Per Kilobase of transcript, per Million mapped reads. 




Supplementary figure 2: Expression of ACE and ACE2 in different human tissues (BioProject accession number: PRJNA270632) [12]. 35 human fetal samples from 6 tissues (3 - 7 replicates per tissue) collected between 10 and 20 weeks gestational time were sequenced using Illumina TruSeq Stranded Total RNA. The plots are adopted and modified from [12]. RPKM- Reads Per Kilobase of transcript, per Million mapped reads. 




Supplementary figure 3: Expression of ACE and ACE2 in different human tissues (BioProject accession number: PRJNA280600) [12]. Transcription profiling by high throughput Illumina sequencing of individual and mixture of 16 human tissues RNA. The plots are adopted and modified from [12]. RPKM- Reads Per Kilobase of transcript, per Million mapped reads.

Supplementary table 1: List of drugs and their binding energies to ACE and ACE2.

Supplementary table 2: Predicted interactions of ACE and ACE2 with RBD of SARS-CoV-2 spike protein. 